\title{
The association of low serum albumin level with severe COVID-19: a systematic review and meta-analysis
}

\author{
Muhammad Aziz ${ }^{1 *}$, Rawish Fatima ${ }^{1}$, Wade Lee-Smith ${ }^{2}$ and Ragheb Assaly ${ }^{3}$
}

Keywords: Hypoalbuminemia, COVID-19, SARS-CoV-2, Severe disease

The coronavirus disease 2019 (COVID-19) pandemic necessitates identifying laboratory markers to assist the clinicians in early recognition of severe disease [1]. Given the unclear association of hypoalbuminemia and severe COVID-19, we conducted a systematic review and metaanalysis to answer this.

An extensive literature search of PubMed/MEDLINE, Embase, Cochrane, and Web of Science was conducted through April 3, 2020, using search strategy created by an experienced librarian (W.L.S). Two independent reviewers (M.A. and R.F.) performed screening and data extraction of articles. Articles were selected if they reported data on COVID-19 patients with respect to hypoalbuminemia. Discrepancy in screening/data collection was resolved through mutual discussion. Random-effects meta-analysis was conducted, and odds ratio (OR) and mean difference (MD) for proportional and continuous variables were computed, respectively. For each outcome, forest plot, 95\% confidence interval $(\mathrm{CI}), p$ value $(<0.05$ considered statistically significant), and $I^{2}$ statistic $(>50 \%$ considered as substantial heterogeneity) was generated using Open Meta Analyst (CEBM, Oxford, UK).

Severe COVID-19 was defined as respiratory distress (with either rate $\geq 30 / \mathrm{min}$, oxygen saturation $\leq 93 \%$ at rest, and/or $\mathrm{PaO} 2 / \mathrm{FiO} 2 \leq 300 \mathrm{mmHg}$ ), $\mathrm{ICU}$ admission, and/or death [1]. Hypoalbuminemia was reported based on reference laboratory parameters for each study.

\footnotetext{
* Correspondence: marajani@hotmail.com

${ }^{1}$ Department of Internal Medicine, University of Toledo Medical Center, Toledo, OH, USA

Full list of author information is available at the end of the article
}

A total of 11 studies (with 910 patients, mean age $47.6 \pm 8.2$ years and $47.0 \%$ females $)$ were included (Table 1). The weighted mean serum albumin on admission was $3.50 \mathrm{~g} / \mathrm{dL}$ (CI $3.26-3.74 \mathrm{~g} / \mathrm{dL}$ ) and $4.05 \mathrm{~g} / \mathrm{dL}$ (CI $3.82-4.27 \mathrm{~g} / \mathrm{dL}$ ) in severe and non-severe COVID-19 group, respectively. This was statistically significant (MD:- $0.56 \mathrm{~g} / \mathrm{dL}, \mathrm{CI}-0.69$ to $-0.42 \mathrm{~g} / \mathrm{dL}, p<0.001, I^{2}=$ 91.2\%)(Fig. 1a). Leave-one-out meta-analysis was consistent with point estimate (MD) ranging from -0.61 to $-0.51 \mathrm{~g} / \mathrm{dL}$ (Fig. 1b). The results were consistent on subgroup analysis of 8 studies that defined severe COVID19 based on respiratory distress definition (MD $-0.58 \mathrm{~g} /$ $\mathrm{dL}, 95 \% \mathrm{CI}-0.78$ to $\left.-0.37 \mathrm{~g} / \mathrm{dL}, p<0.001, I^{2}=87.9 \%\right)$. Four studies assessed the hypoalbuminemia status and severe COVID-19 and increased risk was demonstrated (OR 12.6, 95\% CI 7.5-21.1, $p<0.001, I^{2}=0 \%$ ) (Fig. 1c).

Hypoalbuminemia status has been associated with critically ill patients and mortality across numerous clinical settings [13]. The pathophysiology behind hypoalbuminemia in disease state (such as pancreatitis, infection, trauma, burn, and organ dysfunction) is thought to be secondary to increased capillary permeability, decreased protein synthesis, decreased half-life of serum albumin, decreased serum albumin total mass, increased volume of distribution, and increase expression of vascular endothelial growth factor [14]. The hallmark of severe COVID-19 includes the cytokine storm and an interplay of some of the aforementioned mechanisms [1].

Our study had some limitations. There was lack of reporting on temporal association of hypoalbuminemia 


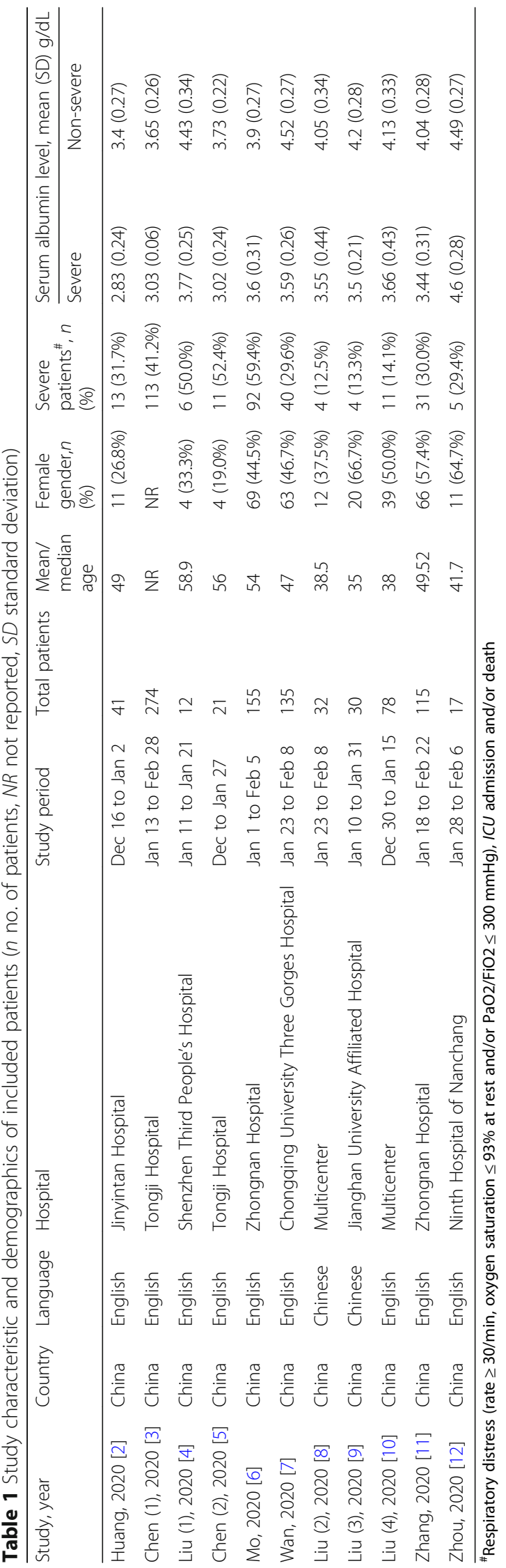




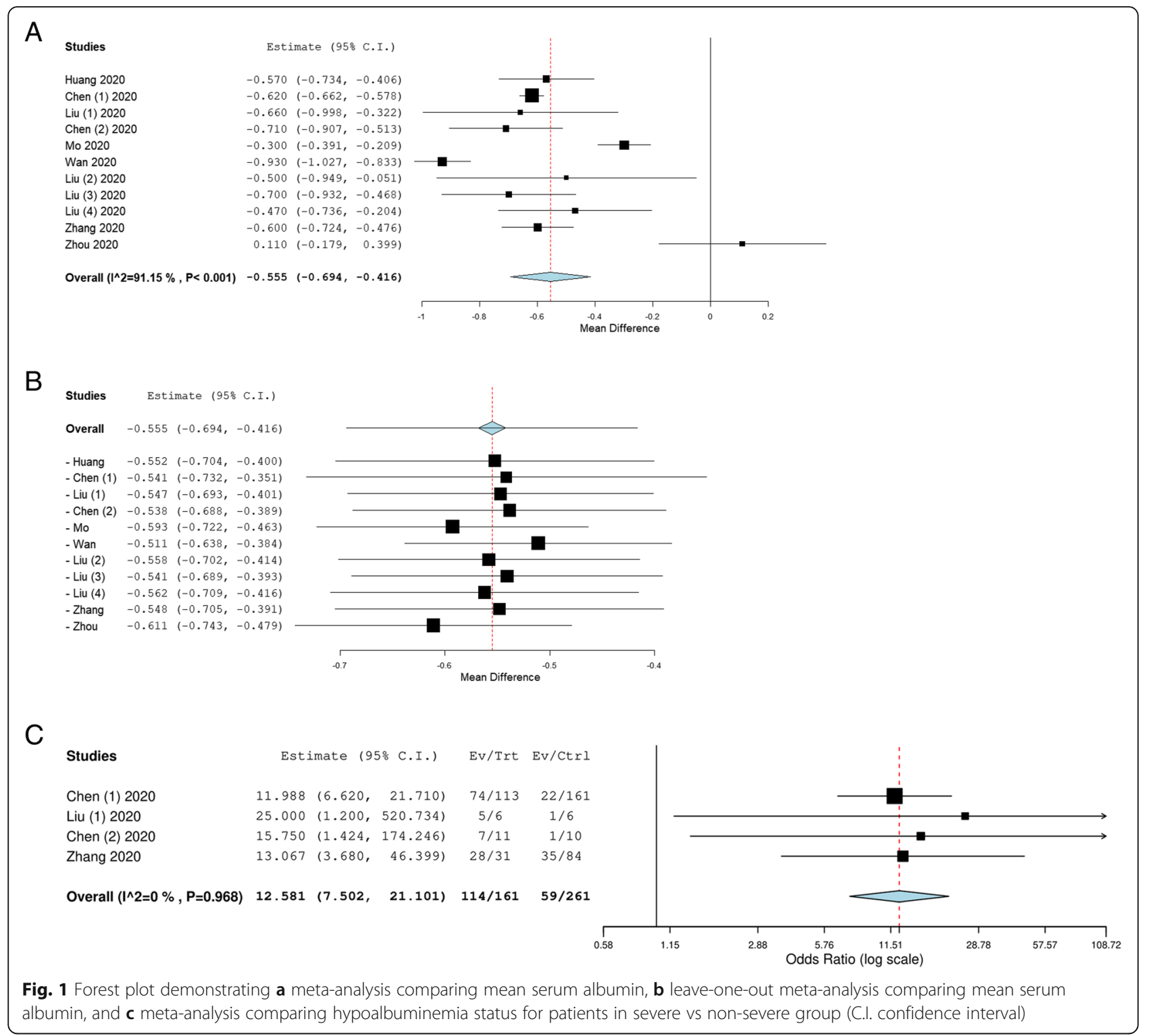

and severe COVID-19. The serum albumin level was noted on admission; however, it is difficult to make conclusive evidence whether severe COVID-19 caused hypoalbuminemia or vice versa. We were also not able to address if hypoalbuminemia should be corrected or not in the current study and needs further evaluation in future studies. The strength of our study is the reporting of large cohort of patients with consistent results across subgroup and sensitivity analysis.

We demonstrate the association of hypoalbuminemia and severe COVID-19. A low albumin level can potentially lead to early recognition of severe disease and assist clinicians in making informed decision for their patients.

\section{Abbreviations}

Cl: Confidence interval; COVID-19: Coronavirus disease 2019; ICU: Intensive care unit; MD: Mean difference; $n$ : No. of patients; OR: odds ratio;

SD: standard deviation

\section{Acknowledgements}

None

\section{Authors' contributions}

Muhammad Aziz: planning and conducting the study, collecting, interpreting data, statistical analysis, drafting the manuscript. Rawish Fatima: collecting data, drafting the manuscript. Wade lee-smith: created the search strategy and critical revision of manuscript. Ragheb Assaly: study design and conception, critical revision of the manuscript. The authors read and approved the final manuscript

Funding

No funding received for preparing this manuscript. 


\section{Availability of data and materials}

The datasets used and/or analyzed during the current study are available from the corresponding author on reasonable request.

\section{Ethics approval and consent to participate}

Not obtained as this is a systematic review and meta-analysis of published studies.

\section{Consent for publication}

Consent from patients not obtained due to reason above. All authors approved for the submission of the manuscript.

\section{Competing interests}

The authors declare no competing/conflict of interest.

\section{Author details}

${ }^{1}$ Department of Internal Medicine, University of Toledo Medical Center, Toledo, OH, USA. ${ }^{2}$ University of Toledo Libraries, University of Toledo Medical Center, Toledo, OH, USA. ${ }^{3}$ Division of Pulmonary and Critical Care Medicine, University of Toledo Medical Center, Toledo, OH, USA.

Received: 4 May 2020 Accepted: 14 May 2020

Published online: 26 May 2020

\section{References}

1. Aziz M, Fatima R, Assaly R. Elevated interleukin-6 and severe COVID-19: a meta-analysis. J Med Virol. 2020. https://doi.org/10.1002/jmv.25948.

2. Huang C, Wang Y, Li X, et al. Clinical features of patients infected with 2019 novel coronavirus in Wuhan, China. Lancet. 2020;395:497-506. https://doi. org/10.1016/S0140-6736(20)30183-5.

3. Chen $T$, Wu D, Chen $H$, et al. Clinical characteristics of 113 deceased patients with coronavirus disease 2019: retrospective study. BMJ. 2020;368: m1091. https://doi.org/10.1136/bmj.m1091.

4. Liu Y, Yang Y, Zhang C, et al. Clinical and biochemical indexes from 2019nCoV infected patients linked to viral loads and lung injury. Sci China Life Sci. 2020;63:364-74. https://doi.org/10.1007/s11427-020-1643-8.

5. Chen G, Wu D, Guo W, et al. Clinical and immunological features of severe and moderate coronavirus disease 2019. J Clin Invest. 2020;130:2620-9. https://doi.org/10.1172/JCl137244.

6. Mo $P$, Xing $Y$, Xiao $Y$, et al. Clinical characteristics of refractory COVID-19 pneumonia in Wuhan, China. Clin Infect Dis. 2020;ciaa270. https://doi.org/10. 1093/cid/ciaa270.

7. Wan S, Xiang Y, Fang W, et al. Clinical features and treatment of COVID-19 patients in northeast Chongqing. J Med Virol. 2020;10.1002/jmv.25783.

8. Liu C, Jiang ZC, Shao CX, et al. Zhonghua Gan Zang Bing Za Zhi. 2020;28: 107-11. https://doi.org/10.3760/cma.j.issn.1007-3418.2020.02.003.

9. Liu M, He P, Liu HG, et al. Zhonghua Jie He He Hu Xi Za Zhi. 2020;43:E016. https://doi.org/10.3760/cma.j.issn.1001-0939.2020.0016.

10. Liu W, Tao ZW, Wang $L$, et al. Analysis of factors associated with disease outcomes in hospitalized patients with 2019 novel coronavirus disease. Chin Med J (Engl). 2020;133:1032-8. https://doi.org/10.1097/CM9. 0000000000000775 .

11. Zhang Y, Zheng L, Liu L, Zhao M, Xiao J, Zhao Q. Liver impairment in COVID-19 patients: A retrospective analysis of 115 cases from a single centre in Wuhan city, China. Liver Int. 2020;10.1111/liv.14455. https://doi.org/ 10.1111/liv.14455.

12. Zhou Y, Zhang Z, Tian J, Xiong S. Risk factors associated with disease progression in a cohort of patients infected with the 2019 novel coronavirus. Ann Palliat Med. 2020;9:428-36. https://doi.org/10.21037/apm. 2020.03.26.

13. Akirov A, Masri-Iraqi H, Atamna A, Shimon I. Low Albumin Levels Are Associated with Mortality Risk in Hospitalized Patients. Am J Med. 2017;130: 1465.e11-65.e19. https://doi.org/10.1016/j.amjmed.2017.07.020.

14. Soeters PB, Wolfe RR, Shenkin A. Hypoalbuminemia: Pathogenesis and Clinical Significance. JPEN J Parenter Enteral Nutr. 2019;43:181-93. https:// doi.org/10.1002/jpen.1451.

\section{Publisher's Note}

Springer Nature remains neutral with regard to jurisdictional claims in published maps and institutional affiliations.

Ready to submit your research? Choose BMC and benefit from:

- fast, convenient online submission

- thorough peer review by experienced researchers in your field

- rapid publication on acceptance

- support for research data, including large and complex data types

- gold Open Access which fosters wider collaboration and increased citations

- maximum visibility for your research: over $100 \mathrm{M}$ website views per year

At $\mathrm{BMC}$, research is always in progress.

Learn more biomedcentral.com/submissions 